\title{
Analisis Fikih Muamalah terhadap Praktek Pemberian Imbalan Penjualan Tanah yang Melibatkan Pihak Ketiga di Desa Sindangsuka Kabupaten Garut
}

\author{
Dea Dwi Lestari, Neneng Nurhasanah, Yandi Maryandi \\ Program Studi Hukum Ekonomi Syariah, Fakultas Syariah, Universitas Islam Bandung \\ J1. Tamansari No. 140116 \\ dwilestaridea22@yahoo.com,nenengnurhasanah@yahoo.com, yandi140985@gmail.com
}

\begin{abstract}
Being an intermediary in buying and selling activities generally looking for profit. In the village of Sindangsuka, the practice of intermediaries in the sale and purchase of land often results in unclear determination of compensation. Rewards are payments received by someone while doing a job. The purpose of this study was to find out how the terms of compensation according to muamalah fiqh in land sale agreements involving third parties, how the practice of giving rewards in land sales in Sindangsuka Village, Garut Regency, and how the muamalah fiqh analysis of the practice of rewarding sale of land involving third parties in Sindangsuka Village, Garut Regency.This research uses a qualitative method with a descriptive analysis approach, the type of research is the field (field research) using data collection methods by observation, interviews and also literature studies.The results of the study concluded that: first, the provision of compensation in the sale of land involving third parties must be in accordance with fiqh muamalah that is clear, accompanied by time, useful, fair, and in accordance with mutual agreement. Second, the practice of providing compensation in the sale of land in the village of Sindangsuka ie there is no written agreement and unclear in the amount of compensation. Third, muamalah fiqih analysis of the practice of giving rewards in Sindangsuka Village is categorized as a ju'alah contract where the remuneration is given at the end after the work is completed, but not all of the pillars and conditions are written, there is no clarity about the amount of compensation given and also the rewards that are given given unfairly, resulting in a loss for one party.
\end{abstract}

Keywords -Fiqh Muamalah, Intermediary, Reward

Abstrak-Menjadi perantara dalam kegiatan jual beli umumnya mencari keuntungan. Di Desa Sindangsuka, praktek perantara dalam jual beli tanah sering terjadi adanya ketidakjelasan dalam penentuan imbalan. Imbalan adalah pembayaran yang diterima oleh seseorang selama melakukan suatu pekerjaan. Tujuan penelitian ini adalah untuk mengetahui bagaimana ketentuan imbalan menurut fikih muamalah dalam akad penjualan tanah yang melibatkan pihak ketiga, bagaimana praktek pemberian imbalan dalam penjualan tanah di Desa Sindangsuka Kabupaten Garut, dan bagaimana analisis fikih muamalah terhadap praktek pemberian imbalan penjualan tanah yang melibatkan pihak ketiga di Desa Sindangsuka Kabupaten Garut. Penelitian ini menggunakan metode kualitatif dengan pendekatan deskriptif analisis, jenis penelitian yaitu lapangan (field research) dengan menggunakan metode pengumpulan data dengan observasi, wawancara dan juga studi literatur. Hasil penelitian menyimpulkan bahwa: pertama, ketentuan imbalan dalam penjualan tanah yang melibatkan pihak ketiga harus sesuai dengan fikih muamalah yaitu jelas, disertai waktu, bermanfaat, adil, dan sesuai dengan kesepakatan bersama. Kedua, praktek pemberian imbalan dalam penjualan tanah di Desa Sindangsuka yaitu tidak ada perjanjian tertulis dan ketidak jelasan dalam besaran imbalan. Ketiga, analisis fikih muamalah terhadap praktik pemberian imbalan di Desa Sindangsuka dikategorikan akad ju'alah dimana pemberian imbalan diberikan diakhir setelah pekerjaan itu selesai, namun tidak terpenuhi seluruh rukun dan syaratnya yaitu perjanjian tidak tertulis, adanya ketidakjelasan mengenai besaran imbalan yang diberikan dan juga imbalan yang diberikan tidak adil, sehingga mengakibatkan adanya kerugian bagi salah satu pihak.

Kata Kunci-Fikih Muamalah, Perantara, Imbalan

\section{PENDAhUluan}

Agama Islam telah mengatur prilaku para pengikutnya dalam segala hal. Salah satunya yaitu tentang hubungan dengan sesama manusia, segala hal tentang masalah tersebut telah dijelaskan dalam ilmu fikih muamalah. Pada umunya di kalangan masyarakat belum sepenuhnya paham akan ketentuan imbalan yang diberikan kepada seseorang menurut fikih muamalah. Sehingga terjadi adanya ketidakjelasan di dalam pemberian imbalan.

Dalam fikih muamalah terdapat bermacam-macam akad yang diantaranya yaitu akad ju'alah, ijarah, hadiah, dan syirkah wujuh yang mempunyai kesamaan mengenai imbalan. Adapun yang membedakannya dapat dilihat dari segi waktu, dimana ju'alah waktunya tidak ditentukan asal pekerjaan itu selesai, sedangkan dalam ijarah waktunya itu harus jelas, dalam hadiah tidak disertai syarat waktu, dan berbeda lagi dengan syirkah wujuh, akad tersebut lebih kepada kerjasama yang keuntungannya dibagi sama antara kedua belah pihak.

Di Desa Sindangsuka Kabupaten Garuti ini, sering terjadi praktek jual beli tanah untuk dijadikan lahan pertanian, perkebunan, dan tanah untuk dijadikan perumahan. Dikarenakan berbagai hal pemilik tanah tidak menjual nya secara langsung melainkan menyuruh orang untuk menjualnya. Pemilik tanah menyuruh orang untuk menjual tanahnya dengan perjanjian akan memberikan imbalan lebih apabila tanah tersebut terjual mahal. 
Pada kenyataannya pelaksanaan pemberian imbalan penjualan tanah di Desa Sindangsuka tidak sesuai dengan ketentuan ju'alah dalam fikih muamalah dan dari sudut pandang peneliti sendiri. Dikatakan praktek ju'alah karena pemberian imbalan terhadap penjualan tersebut mengarah kepada ju'alah dimana pembayaran imbalan dilakukan setelah pekerjaan itu selesai, tanpa disertai waktu. Permasalahan yang terjadi disini besaran imbalan tersebut tidak diketahui pada saat awal perjanjian. Pemilik tanah hanya menyebutkan jika tanahnya terjual mahal maka orang itu akan mendapatkan imbalan.

\section{LANDASAN TEORI}

\section{A. Akad-Akad Imbalan dalam Fikih Muamalah}

\section{Akad Ijarah}

Ijarah adalah suatu jenis perikatan atau perjanjian yang bertujuan mengambil manfaat suatu benda yang diterima dari orang lain dengan jalan membayar upah sesuai dengan perjanjian dan kerelaan kedua belah pihak dengan rukun dan syarat yang telah ditentukan.

Dalam pembayaran upah dan sewa itu ada ketentuannya yaitu jika ijarah merupakan suatu pekerjaan, maka kewajiban pembayaran upahnya pada waktu berakhirnya pekerjaan. Bila tidak ada pekerjaan lain, dan akad sudah berlangsung tidak pula disyaratkan mengenai pembayaran dan tidak ada ketentuan penangguhannya. berikut:

Upah berhak diterima oleh pekerja dengan ketentuan

a. Apabila pekerjaan telah selesai dikerjakan. Ibnu Majah meriwayatkan bahwa Rasulullah bersabda "berikanlah upah kepada bekerja sebelum keringatnya kering".

b. Mendapat manfaat apabila akad dilakukan pada barang. Apabila barang tersebut rusak sebelum diambil manfaatnya dan masa penyewaan belum berlalu, maka penyewaan batal.

c. Adanya kemungkinan untuk mendapatkan manfaat. Jika masa sewa berlangsung, ada kemungkinan untuk mendapatkan manfaat dari barang sewaan meskipun tidak sepenuhnya.

d. Mendahulukan pembayaran sewa atau kesepakatan bersama untuk menangguhkan biaya sewa. ${ }^{1}$

\section{Akad Syirkah Wujuh}

Syirkah Wujuh yaitu kerja sama antara dua orang atau lebih untuk membeli sesuatu tanpa modal, tetapi hanya modal kepercayaan dan keuntungan dibagi antara sesama mereka. $^{2}$

Ketentuan Imbalan dalam Akad Syirkah Wujuh

a. Modal syirkah wujuh diketahui.

b. Modal syirkah wujuh ada pada saat transaksi. c. Besarnya keuntungan diketahui dengan penjumlahan yang berlaku, seperti setengah dan lainnya.

d. Untung dan rugi diatur dengan perbandingan modal masing-masing.

\section{B. Hadiah}

hadiah adalah pemberian sesuatu kepada seseorang dengan maksud untuk memuliakan atau memberikan penghargaan. Hadiah adalah pemberian yang dimaksudkan untuk mengagungkan atau rasa cinta. 3 Maka, hadiah merupakan pemberian harta kepada seseorang untuk membuat senang tanpa adanya paksaan dari keduanya.

\section{Ju'alah}

Secara bahasa, ju'alah adalah janji untuk memberikan imbalan atau award/ja'izah (al-ju'alah aw al-wa'd bi ja'izah) kepada pihak lain apabila berhasil mecapai natijah tertentu.4

Jualah adalah suatu pemberian upah/ imbalan kepada orang telah melaksanakan pekerjaan, akan tetapi, apabila suatu pekerjaan yang dikerjakan tidak berhasil maka tidak akan mendapatkan upah/ imbalan.

Allah memerintahkan kepada para pemberi upah untuk berlaku adil, berbuat baik dan dermawan kepada penerima upah. Upah atau ujrah dapat diklasifikasikan menjadi dua: pertama, upah yang telah disebutkan, upah ini disyaratkan ketika disebutkan harus disertai kerelaan kedua pihak yang bertransaksi dan kedua, upah yang sepadan, yakni upah yang sepadan dengan kerja keras serta kondisi pekerjaannya. Dalam hal pemberian upah harus ditetapkan secara jelas dalam akad. Jika masanya ditetapkan, maka kadar harga pengupahan yang harus diberikan juga harus di tetapkan.

\section{Penjualan Tanah yang Melibatkan Pihak Ketiga}

\section{Samsarah}

Pada umumnya di dalam transaksi jual beli terdapat perantara, perantara disebut dengan simsar yaitu seseorang yang menjualkan barang orang lain atas dasar bahwa seseorang itu akan diberi upah oleh yang punya barang sesuai dengan usahanya. ${ }^{5}$ Samsarah adalah perantara perdagangan (orang yang menjualkan barang dan mencarikan pembeli), atau perantara antara penjual dan pembeli untuk memudahkan jual beli. ${ }^{6}$ 


\section{c. Wakalah}

Wakalah menurut bahasa artinya adalah al-hifdz, alkifayah, al-dhaman dan al-tafwidh yang berarti penyerahan, pendelegasian,dan pemberian mandat.7 Dalam wakalah sebenarnya pemilik urusan (muwakil) itu dapat secara sah untuk mengerjakan pekerjaannya sendiri. Namun, karena satu dan lain hal urusan itu ia serahkan kepada orang lain yang dipandang mampu untuk menggantikannya. Sehingga wakalah dapat diartikan sebagai penyerahan sesuatu oleh seseorang yang mampu dikerjakan sendiri sebagian dari suatu tugas yang bisa diganti kepada orang lain, agar orang itu mengerjakannya semasa hidupnya. ${ }^{8}$

\section{HASIL PENELITIAN DAN PEMBAHASAN}

A. Ketentuan Imbalan Menurut Fikih Muamalah dalam Akad Penjualan Tanah yang Melibatkan Pihak Ketiga

Ketentuan imbalan dalam fikih muamalah disyaratkan imbalan:

1. Imbalan hendaklah jelas dengan bukti dan ciri yang bisa menghilangkan ketidakjelasan dan disebutkan besar dan bentuk imbalan.

2. Imbalan harus dibayarkan sesegera mungkin atau sesuai dengan waktu yang telah ditentukan dalam akad.

3. Imbalan tersebut bisa dimanfaatkan oleh pekerja untuk memenuhi kebutuhan kehidupannya.

4. Imbalan yang diberikan haruslah adil bagi kedua belah pihak.

e. Imbalan yang diberikan harus sesuai. Maksud dari sesuai adalah sesuai dengan kesepakatan bersama, tidak dikurangi dan tidak ditambahi. ${ }^{9}$

\section{B. Praktek Pemberian Imbalan dalam Penjualan Tanah di Desa Sindangsuka Kabupaten Garut}

Perjanjian dalam penjualan tanah yang dilakukan oleh masyarakat di Desa Sindangsuka sudah seperti pada umumnya. Dimana seorang perantara mendatangi rumahrumah pemilik tanah, lalu mereka melakukan perjanjian harga yang telah ditetapkan, dengan imbalan yang diberikan pemilik tanah kepada perantara akan dibayar setelah tanahnya terjual dan tidak diketahui besarannya. Setelah itu, perantara menghubungi para investor yang sedang membutuhkan lahan untuk sebuah pembangunan yang mana perantara menjualnya dengan harga yang lebih tinggi dari yang telah disepakati tanpa sepengetahuan pemilik tanah, karena imbalan yang diberikan oleh pemilik tanah tidak sesuai dengan usahanya.
E. Analisis Fikih Muamalah terhadap Praktek Pemberian Imbalan Penjualan Tanah yang Melibatkan Pihak Ketiga di Desa Sindangsuka Kabupaten Garut

Perdagangan yang di dalamnya mengandung unsur ketidakjelasan, ketidakjujuran, pemaksaan dan penipuan sehingga membuat orang lain kecewa dan tidak ikhlas menjual barang, selain itu juga mengorbankan kepentingan orang lain, karena jual beli akan menjadi halal ketika terjadi dengan rasa suka sama suka tidak ada unsur keterpaksaan selain itu juga menghabat kepentingan orang lain untuk mendapatkan keuntungan diri sendiri, jual beli yang benar adalah ketika kita melakukan jual beli salah satu diantara yang melakukan akad tidak merasa dirugikan.

Di desa Sindangsuka sistem perjanjian atau kesepakatan antara pemilik tanah dengan perantara hanya didasarkan pada penjanjian lisan saja. Di dalam perjanjian antara pemilik tanah dan perantara tidak ada hitam diatas putih atau tidak tertulis. Sehingga tidak memiliki kekuatan hukum. Pemilik tanah hanya menyebutkan dengan lisan sistem pemberian imbalan bagaimana, apakah diawal atau diakhir dan tidak menyebutkan berapa besaran upah yang harus dibayarkannya kepada perantara.

Dalam fikih muamalah pemberian imbalan dilakukan ketika terjadi kesepakatan diawal saat melakukan transaksi, agar tidak ada kerugian dalam kedua belah pihak. Namun, dalam pemberian imbalan kepada perantara tidak disebutkan dengan jelas berapa besaran nominalnya yang akan diberikan. Dan pemilik tanah hanya akan memberikan imbalan kepada perantara jika perantara mampu menjualkan tanah yang dijualnya. Hal ini tercantum dalam dalam Al-Qur'an Surat an-Nahl ayat 90:

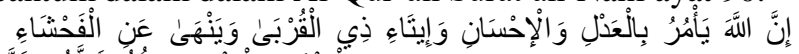

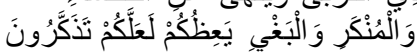

"Sesungguhnya Allah menyuruh (kamu) Berlaku adil dan berbuat kebajikan, memberi kepada kaum kerabat, dan Allah melarang dari perbuatan keji, kemungkaran dan permusuhan. Dia memberi pengajaran kepadamu agar kamu dapat mengambil pelajaran "10

Berdasarkan uraian diatas, penulis menyimpulkan bahwa transaksi penjualan tanah di Desa Sindangsuka tersebut dikategorikan kepada akad ju'alah, dimana dalam pemberian imbalannya diberikan diakhir setelah pekerjaan itu selesai. Namun, tidak terpenuhi seluruh rukun dan syaratnya yaitu tidak ada kejelasan mengenai besaran imbalan dan imbalan yang diberikan tidak adil sehingga mengakibatkan adanya kerugian bagi salah satu pihak. 


\section{SIMPULAN}

1. Pemberian imbalan dalam penjualan tanah harus sesuai dengan ketentuan imbalan dalam fikih muamalah yaitu adanya kejelasan, imbalan yang diberikan harus sesuai dengan waktu yang disepakati, bermanfaat, adil, dan sesuai dengan kesepakatan bersama.

2. Praktik pemberian imbalan terhadap penjualan tanah di Desa Sindangsuka dilakukan tanpa adanya perjanjian tertulis antara pemilik tanah dan perantara, sehingga tidak ada kejelasan mengenai besaran imbalan yang diberikan. Dalam praktiknya di lapangan, pemilik tanah hanya memberikan informasi kepada perantara bahwa tanah yang akan dijualnya sesuai dengan harga yang telah diminta oleh pemilik tanah. Dengan demikian pemberian imbalan yang diberikan tidak adanya perjanjian yang di sepakati.

3. Transaksi penjualan tanah di Desa Sindangsuka tersebut dapat dikategorikan akad ju'alah, dimana dalam pemberian imbalannya diberikan diakhir setelah pekerjaan itu selesai, namun tidak terpenuhi seluruh rukun dan syaratnya yaitu tidak ada kejelasan mengenai besaran imbalan yang diberikan dan juga imbalan yang diberikan tidak adil, sehingga mengakibatkan adanya kerugian bagi salah satu pihak.

\section{DAFTAR PUSTAKA}

[1] Annisa, Vina. (2015). Tinjauan Hukum Islam Terhadap Sistem Penetapan Harga dan Laba dalam Jual Beli Sepeda Motor di Showroom Rejeki Motor Cepiringi. Semarang: UIN Walisongo.

[2] Basyir, Ahmad Azhar. (2000). Asas-Asas Hukum Muamalat, Yogyakarta: UII Pers.

[3] Departemen Agama RI. (2012). Al-Hikmah. Bandung: Diponegoro.

[4] Hasan, M. Ali. (2003). Berbagai Transaksi Dalam Islam (Fiqh Muamalat). Jakarta: PT RajaGrafindo Persada.

[5] Mubarok, Jaih dan Hasanudin. (2017). Fikih Mu'amalah Maliyyah: Akad Ijarah dan Ju'alah. Bandung: Simbiosa Rekatama Media.

[6] Muhammad, Abu Bakar. (1995). Fiqh Islam. Surabaya: Karya Abbditama.

[7] Syafei, Rachmad. (2001). Fiqih Muamalah. Bandung: Pustaka Ceria.

[8] Suhendi, Hendi. (2010). Fiqh Muamalah. Jakarta: PT RajaGrafindo Persada. 